strong fabric of the State, our various specialities must overlap and intertwine like the fibres of a woven cloth. The strength of the fabric depends upon that overlapping : indeed tho strongth of the singlo fibre depends on the overlapping of the separate crystallites.

Our scientific workers should be well able to use their native tongue, well able to arrange their thoughts, arguments and conclusions, and to put them into language that will be understood. The ideal ruler of Plato's State was to be versed in all that he called philosophy, including science, music, physical culture, the arts of war, and above all, the pursuit of that which was good. To-day there is no such super-man. But it is possible to include in the national team all those excellencies, distributed over many individuals. The one thing necessary is that they should appreciate each other's point of view and mode of thought.

Prof. J. V. Philip lectured on "Chemical Fogs" and intrigued his audience with his speculations as to the effects of ammonia on the incidence of fogs. Prof. J. W. Munro spoke on recent advances in economic entomology and pointed out that the tendency. to-day is to emphasise the importance of the zoological aspect. In fact, the economic entomological problems are really one zoological problem, namely, that of the fluctuations in insect numbers and their causes.

Dr. John Taylor greatly interested the Association by showing how science assists the forces of the law, and Dr. H. J. T. Ellingham elucidated the intricacies of the "Simple Cell". Mr. H. R. Hewer showed a selection of biological films produced by GaumontBritish and directed by himself with the assistance of Prof. Julian Huxley. Some of these were quite new and had not previously been shown: their excellence was freely commented upon. Mr. B. K. Johnson demonstrated some lecture experiments in optics, including a model eye for showing defects of vision and their remedies.

The members themselves took part in three meetings devoted to discussions : the subjects dealt with were "Laboratory Design and Equipment", "Sign Conventions in Geometrical Optics" and "School Certificate Biology". All of these were well attended.

At the business meeting, the following elections took place: President, Prof. J. S. B. Stopford; Secretary, S. V. Brown (Liverpool Institute); Treasurer, B. M. Neville (William Ellis School); Annual Meeting Secretary, R. E. Williams (Repton); New Members of Committee, J. L. Brereton (Cambridge), W. Ashhurst (Stretford Grammar School), W. G. Greaves (Ledbury Grammar School) and H. G. Lambert (Moseley Secondary School). Prof. J. H. Priestley, of the University of Leeds, and Mr. F. B. Stead were elected honorary members. The annual report showod that the Association has now more than 2,000 members and that branches in Yorkshire and East Anglia have been formed during the year.

The annual meeting for 1937 will be held in Manchester under the presidency of Prof. J. S. B. Stopford.

\title{
Culture and Education among the Modern Eskimo of Alaska*
}

\begin{abstract}
$\mathrm{A}^{\mathrm{S}}$ the result of a proposal made by $\mathrm{Mr}$. Wm. A John Cooper, Commissioner for Education of the United States, at a meeting of the Council for Education in 1929, and with the financial assistance of the Carnegie Corporation of New York, an investigation covering a period of two years was undertaken among the natives of Alaska for the purpose of examining conditions in the system of education, and suggesting modifications, if any, necessary to bring it into greater harmony with the racial character and probable future development of the Eskimo.
\end{abstract}

Alaska was acquired by the United States in 1867, and the natives-Eskimo, Aleuts and Athabascan Indians-were brought under the control of the Board of Education in 1887, since when the system of education applicable to the United States as a whole has applied to them. On his appointment as Commissioner for Education in 1929, Mr. Cooper proposed to establish a Division of Indigenous Peoples, under which each people should be treated in accordance with its needs. The present investigation was a part of that proposal. It was entrusted to members of the Sehool of Education of Stanford University ; but Mrs. Anderson, who accompanied the expedition in the field, had had experience in the application of the Stanford-Binet intelligence tests.

The method of investigation was (1) to compile as complete a picture as possible of the physical * Alaska Natives : a Survey of their Sociological and Educational Status. By Dr. H. Dewey Anderson and Prof. Walter Crosby Eells. Made under the auspices of the School of Education of Stanford University at the request of the United States Office of Education, supported by a Grant from the Carnegie Corporation of New York, Pp. xvi +472 . (Stanford University, Calif. : Stanford University
Press; London : Oxford University Press, 1935.) 22s. 6d. net. characters, demography and culture of the Eskimo when first encountered by whites, from the records of early travellers; (2) to investigate and record the same features among the Eskimo of the present day from personal observation in the field and contemporary records of anthropologists and others ; (3) to inspect existing methods of education with special reference to their efficiency and suitability to the needs and character of the culture of the modern Eskimo ; and (4) to endeavour to form an estimate of the trend of development for which provision should be made in educational and administrative policy.

The general trend of change in culture is perhaps best indicated by the recommendations which deal with the economic and social position. It is probable that the native population will increase rather than decrease. Tribal fusion will take place. This movement is already in progress, but it is hampered in some degree by the language difficulty. This will be overcome as the use of English spreads. The settlement in villages, which is at present taking place, will be accelerated. The native type of house, already dying out, will disappear. Where no hardship is involved by the removal from traditional fishing and hunting grounds, the tribes might be settled in villages, giving them the advantage of the better sanitation of the European type of house, especially if built on an improved plan with better methods of heating, such as the use of coal. Village club houses should be built to take the place of the old group kashgii. Village councils and co-operative enterprises should be fostered, the latter as a protective measure against the competitive economic methods of the white 
population. Whites not actually engaged in activities promoting the life of the native community should not be allowed to reside in the native settlements. The social status of the increasing number of halfbreeds should be protected.

In the investigation of the existing system of education, which has been organised entirely on the model of the American school system, administration, staff, buildings, as well as the character and attainments of the scholars, were inspected. In the testing of the scholars, both intelligence and attainment tests were applied.

In the intelligence tests, $45 \cdot 8$ per cent of a school enrolment of 2,302 were tested, of whom $57 \cdot 2$ (651) were counted as of pure blood. Mental, physical and mechanical ability were tested. So far as possible, adaptations in the tests were made to meet the difficulties of environment and language. The results of the Stanford-Binet tests gave an intelligence quotient of :-Eskimo, mean $73 \cdot 67$, standard deviation $12 \cdot 78$; Aleut, mean $80 \cdot 27$, s.d. 13.94; Indian, mean $78 \cdot 98$, s.d. $14 \cdot 94$ (White $=100$ ). This places the Eskimo at slightly above the American Indian and at about the same level as the southern
Negro ; but in view of the absence of white contacts, it is probable that the Alaska figures represent a slightly higher level than those with which they are compared. It is interesting to note that whereas the intelligent quotient shows a tendency to increase with an increase in the amount of white blood in the subject, it decreases with an increase in the amount of school attendance.

In the physical tests, visual and auditory acuity show little difference from American white children.

In the detailed investigation of results obtained in the subjects of the curriculum, inferiority was shown in all classes of school, Eskimo, Aleut and Indian. This, however, must not be taken to argue inferior ability, but is rather the result of a thoroughly unsuitable curriculum. As an example in the calendar observances, on Arbor Day, the children of a treeless land are concerned with the planting and cultivation of trees and the implements used therein. As a whole, the curriculum is condemned and its modification recommended so that it may be no longer 'subject. centred' as at present, but may be concerned with "activities fundamental to the economic and social life and well-being of the natives".

\section{Forest Products Research in Great Britain*}

$\mathrm{T}$ HE report of the Forest Products Research Board for 1934 has been recently issued. With the report is the annual report of the director of forest products research, 1934. The Research Board met twice during the year. At its first meeting, the Board undertook a general revision of the programme of research of the Laboratory, the effect aimed at being to secure a greater elasticity in the working of the various projects. The second meeting held at the Laboratory enabled the members of the Board to visit the various sections, and to study the progress being made. Two important questions which have engaged the attention of the Board have been connected with, first, the provision of means of closer contact between the work of the Laboratory and timber-using industries and growers in the north of England and Scotland; and secondly, the development of research into problems connected with woodworking. The report states that full advantage has been taken of the facilities offered by the Laboratory for investigating the properties and working qualities of timbers from various oversea units of the Empire.

The director's report deals with the experiments connected with the working or seasoning of more than fifty species of timber so as to remove the cause of badly fitting doors and windows, research in the utilisation of home-grown timbers, experimental work with the cricket-bat willow and research work into the death:watch beetle and other insect pests, and into dry rot and other fungal attack. The report alludes to two important problems which are facing, and will face the new afforestation work in Great Britain. These are connected with, (1) the effects of pruning trees on the quality of the timber, and (2) the utilisation of thinnings. The practical and economic possibility of producing higher grades of

* Department of Scientific and Industrial Research: Report of Forest Products Research Board, with the Report of the Director of
Forest Products Research, for the Year 1934. Pp. vi $+75+2$ plates. Forest Products Research, for the Year 1934. Pp. vi
(London : H.M. Stationery Office, 1935.) 18. 6 d. net. timber by pruning standing trees is a question of the first importance to foresters and timber growers. The sylvicultural aspects of this problem are being studied in the field by the Forestry Commission in a comprehensive working plan, and the Laboratory is examining the results of pruning. These latter cover the rate at which occlusion takes place and the extent of grain disturbance, and also the improvement in grade that may be expected in lumber from trees pruned at various ages and to different heights.

Arrangements have been made for the continuation of this work during 1935 .

It is well understood by foresters that the best quality of timber is produced by keeping the young crop of trees dense so as to engender clean growth of the young stems, the branches being killed owing to the close overhead canopy. In planting work, this means a large number of plants to the acre. The pruning experiments have for their object the reduction of the initial planting costs through wider spacing of the young trees.

In connexion with the utilisation of thinnings, the report states that the manufacture of pulp and wallboard appears to offer one solution, and preliminary steps have been taken to determine whether industries can absorb the thinnings. In collaboration with an important pulp-grinding firm, and with timbergrowing bodies, an investigation is being made into the suitability for pulping of home-grown timber from different localities and grown under different conditions. This project is also being continued.

The Forestry Commission has now planted some 250,000 acres of young woods. The formidable task of commencing the thinnings of the older age classes in this large area is beginning to loom on the horizon as a problem of increasing importance. The problem is a two-headed one, consisting of the correct sylvicultural operation to be carried out in the woods, and the subsequent disposal of the material taken out, at a satisfactory price. 